\title{
Intracellular $\mathrm{Na}^{+}$Controls Cell Surface Expression of Na,K-ATPase via a cAMP-independent PKA Pathway in Mammalian Kidney Collecting Duct Cells
}

\author{
Manlio Vinciguerra, ${ }^{*}$ Georges Deschênes, ${ }^{+}$Udo Hasler, ${ }^{*}$ David Mordasini, ${ }^{*}$ \\ Martine Rousselot, ${ }^{*}$ Alain Doucet,, Alain Vandewalle, $\$$ Pierre-Yves Martin, ${ }^{*}$ \\ and Eric Féraille*II
}

\author{
*Division de Néphrologie, Fondation pour Recherches Médicales, CH-1211 Genève 4, Switzerland; \\ 'Service de Néphrologie Pédiatrique, Hôpital A. Trousseau, F-75571 Paris cedex 12, France; \\ ‡Laboratoire de Physiologie et Génomique des Cellules Rénales, FRE 2468, Institut des Cordeliers, IFR \\ 58, 75270 Paris cedex 6, France; and \$INSERM U478, Faculté de Médecine Xavier Bichat, BP416, \\ F-75870 Paris Cedex 18, France
}

Submitted November 11, 2002; Revised February 13, 2003; Accepted March 13, 2003

Monitoring Editor: Guido Guidotti

\begin{abstract}
In the mammalian kidney the fine control of $\mathrm{Na}^{+}$reabsorption takes place in collecting duct principal cells where basolateral $\mathrm{Na}, \mathrm{K}-\mathrm{ATPase}$ provides the driving force for vectorial $\mathrm{Na}^{+}$transport. In the cortical collecting duct (CCD), a rise in intracellular $\mathrm{Na}^{+}$concentration $\left(\left[\mathrm{Na}^{+}\right] \mathrm{i}\right)$ was shown to increase $\mathrm{Na}, \mathrm{K}-\mathrm{ATP}$ ase activity and the number of ouabain binding sites, but the mechanism responsible for this event has not yet been elucidated. A rise in $\left[\mathrm{Na}^{+}\right]$i caused by incubation with the $\mathrm{Na}^{+}$ionophore nystatin, increased $\mathrm{Na}, \mathrm{K}-\mathrm{ATPase}$ activity and cell surface expression to the same extent in isolated rat CCD. In cultured mouse mpkCCD ${ }_{\mathrm{cl} 4}$ collecting duct cells, increasing $\left[\mathrm{Na}^{+}\right]$i either by cell membrane permeabilization with amphotericin $\mathrm{B}$ or nystatin, or by incubating cells in a $\mathrm{K}^{+}$-free medium, also increased $\mathrm{Na}, \mathrm{K}-\mathrm{ATPase}$ cell surface expression. The $\left[\mathrm{Na}^{+}\right] \mathrm{i}$-dependent increase in $\mathrm{Na}, \mathrm{K}-\mathrm{ATPase}$ cell-surface expression was prevented by PKA inhibitors H89 and PKI. Moreover, the effects of $\left[\mathrm{Na}^{+}\right] \mathrm{i}$ and cAMP were not additive. However, $\left[\mathrm{Na}^{+}\right] \mathrm{i}$-dependent activation of PKA was not associated with an increase in cellular cAMP but was prevented by inhibiting the proteasome. These findings suggest that $\mathrm{Na}, \mathrm{K}-\mathrm{ATPase}$ may be recruited to the cell membrane following an increase in $\left[\mathrm{Na}^{+}\right] \mathrm{i}$ through cAMP-independent PKA activation that is itself dependent on proteasomal activity.
\end{abstract}

\section{INTRODUCTION}

The kidney plays a major role in the homeostasis of body fluid compartments in mammals. Despite the large quantitative variations in dietary intake of solutes and water, the kidneys are able to maintain within a narrow range the composition and volume of extracellular and intracellular fluid compartments. The fine-tuning of $\mathrm{Na}^{+}$reabsorption, tightly controlled by hormonal and nonhormonal factors, occurs at the level of the renal collecting duct. In this nephron segment, $\mathrm{Na}^{+}$reabsorption takes place via a transcellular route in collecting duct principal cells. $\mathrm{Na}^{+}$enters into principal cells via the luminal epithelial $\mathrm{Na}^{+}$channel $(\mathrm{ENaC})$

Article published online ahead of print. Mol. Biol. Cell 10.1091/ mbc.E02-11-0720. Article and publication date are available at www.molbiolcell.org/cgi/doi/10.1091/mbc.E02-11-0720.

II Corresponding author. E-mail address: Eric.Feraille@medecine. unige.ch.

Abbreviations used: PKA, protein kinase A; CCD, cortical collecting duct; AEBSF, 4-(2-aminoethyl)benzenesulfonyl fluoride. and is extruded by the basolateral $\mathrm{Na}, \mathrm{K}-\mathrm{ATPase}$. The $\mathrm{Na}, \mathrm{K}$ ATPase, which provides the driving force for active $\mathrm{Na}^{+}$and $\mathrm{K}^{+}$ transport, and secondary active transport of other solutes (Skou, 1998), is tightly regulated (Therien and Blostein, 2000; Féraille and Doucet, 2001). Long-term regulation of $\mathrm{Na}$,K-ATPase relies mainly on alteration of the expression of its subunits, whereas short-term control is mediated by changes in enzymatic turnover and/or redistribution between cell surface and intracellular compartments.

In the mammalian cortical collecting duct (CCD), a rise in intracellular $\mathrm{Na}^{+}$concentration $\left(\left[\mathrm{Na}^{+}\right] \mathrm{i}\right)$ rapidly increases the activity of $\mathrm{Na}, \mathrm{K}-\mathrm{ATP}$ ase and the number of specific ouabain binding sites (Barlet-Bas et al., 1990b; Blot-Chabaud et al., 1990). It has been shown that $\left[\mathrm{Na}^{+}\right] \mathrm{i}$-dependent increase of $\mathrm{Na}, \mathrm{K}$-ATPase activity does not require transcriptional regulation and/or de novo protein synthesis (Barlet-Bas et al., 1990b). These findings raise the possibility that silent Na-pumps already located at the cell membrane are activated or alternatively, that preexisting intracellular $\mathrm{Na}, \mathrm{K}-\mathrm{ATPase}$ units are shuttled to the cell surface. The latter 


\section{Cell surface}

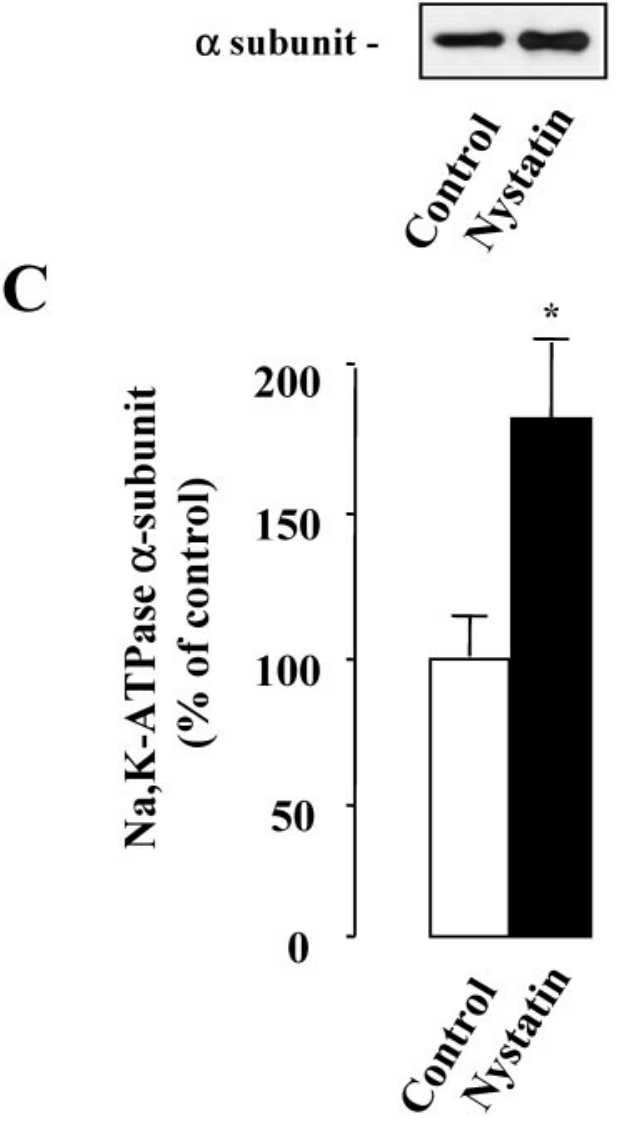

Figure 1. Effect of high $\left[\mathrm{Na}^{+}\right] \mathrm{i}$ on $\mathrm{Na}, \mathrm{K}-\mathrm{ATPase}$ activity and cell surface expression in isolated rat CCDs. The activity (A) and cell surface expression (B and $C$ ) of $\mathrm{Na}, \mathrm{K}-\mathrm{ATP}$ ase were analyzed on microdissected CCDs incubated without (control) or with $0.1 \mathrm{U} / \mu \mathrm{l}$ nystatin for $1 \mathrm{~h}$ at $37^{\circ} \mathrm{C}$. (A) The activity of $\mathrm{Na}, \mathrm{K}-\mathrm{ATPase}$ was determined under $V_{\max }$ conditions on freeze/thawing permeabilized CCDs. Results are expressed as pmol ATP $\times \mathrm{mm}^{-1} \times \mathrm{h}^{-1}$ and are means \pm SE from five animals. ${ }^{*} \mathrm{p}<0.05$. (B and C) The $\mathrm{Na}, \mathrm{K}-$ ATPase $\alpha$-subunit was detected by Western blotting performed after biotinylation and streptavidin precipitation of cell surface proteins. (B) Representative immunoblot showing $\mathrm{Na}, \mathrm{K}-\mathrm{ATPase}$ cell surface expression. (C) Bars represent densitometric values expressed as the percentage of the optical density value obtained from untreated samples (control). Results are means \pm SE from eight animals. ${ }^{*} \mathrm{p}<0.05$ vs. control values. hypothesis was supported by recent experimental evidence showing that an intracellular pool of $\mathrm{Na}, \mathrm{K}-\mathrm{ATPase}$ units can be rapidly recruited to the cell surface in response to CAMP (Gonin et al., 2001) or to aldosterone (Summa et al., 2001).

The aim of the present study was to investigate the effect of an increase in $\left[\mathrm{Na}^{+}\right]$i on $\mathrm{Na}, \mathrm{K}-\mathrm{ATP}$ ase cell surface expression in CCD cells and to determine the intracellular signaling pathway mediating this effect. To answer these questions, we used both microdissected intact rat CCDs and confluent cultured mouse principal collecting duct mpkCCD $_{\text {c14 }}$ cells (Bens et al., 1999), a cell line characterized by retained-expression of transporters specific for CCD principal cells including $\mathrm{ENaC}$ and aquaporin-2 as well as by controlled transepithelial $\mathrm{Na}^{+}$transport by aldosterone and vasopressin (Bens et al., 1999; Vandewalle et al., 1999; RobertNicoud et al., 2001; Hasler et al., 2002),

\section{MATERIALS AND METHODS}

\section{Isolated Rat Kidney Tubules}

Male Wistar rats (150-200 g body weight; Centre Médical Universitaire, Genève, Switzerland) were anesthetized with intraperitoneal injection of pentobarbital ( $5 \mathrm{mg} / 100 \mathrm{~g}$ of body weight). After laparotomy, the left kidney was perfused with an incubation solution
(120 mM NaCl, $5 \mathrm{mM} \mathrm{RbCl}, 4 \mathrm{mM} \mathrm{NaHCO}, 1 \mathrm{mM} \mathrm{CaCl}_{2}, 1 \mathrm{mM}$ $\mathrm{MgSO}_{4}, 0.2 \mathrm{mM} \mathrm{NaH} \mathrm{PO}_{4}, 0.15 \mathrm{mM} \mathrm{Na} \mathrm{HPO}_{4}, 5 \mathrm{mM}$ glucose, 10 $\mathrm{mM}$ lactate, $1 \mathrm{mM}$ pyruvate, $4 \mathrm{mM}$ essential and nonessential amino acids, $0.03 \mathrm{mM}$ vitamins, $20 \mathrm{mM}$ HEPES, $\mathrm{pH}$ 7.45) supplemented with $0.44 \%$ (wt/vol) collagenase (CLSII, $0.75-0.87 \mathrm{U} / \mathrm{mg}$ ). Afterward, the kidney was removed, sliced into small pyramids, and incubated for $20 \mathrm{~min}$ at $30^{\circ} \mathrm{C}$ in an oxygenated $\left(95 \% \mathrm{O}_{2}\right.$ and $5 \% \mathrm{CO}_{2}$ ) incubation solution containing $0.08 \%(\mathrm{wt} / \mathrm{vol})$ collagenase, as described previously (Gonin et al., 2001). Single CCDs were isolated by microdissection in the ice-cold oxygenated incubation solution containing aprotinin $(1 \mu \mathrm{g} / \mathrm{ml})$ and leupeptin $(20 \mathrm{mg} / \mathrm{ml})$ to preserve the integrity of proteins. Isolated CCDs were incubated with or without drugs for $2 \mathrm{~h}$ at $37^{\circ} \mathrm{C}$ as described in RESULTS. The length of tubular segments, which served as reference for Na,K-ATPase activities and Western blotting analysis was determined from photographs of microdissected CCDs.

\section{Cell Culture}

The mpkCCD ${ }_{\mathrm{c} 14}$ cells (passages 20-25) were grown in defined medium (DM: DMEM:Ham's F 12 1:1 [vol/vol], $60 \mathrm{nM}$ sodium selenate, $5 \mu \mathrm{g} / \mathrm{ml}$ transferrin, $2 \mathrm{mM}$ glutamine, $50 \mathrm{nM}$ dexamethasone, $1 \mathrm{nM}$ triiodothyronine, $10 \mathrm{ng} / \mathrm{ml}$ epidermal growth factor, $5 \mu \mathrm{g} / \mathrm{ml}$ insulin, $20 \mathrm{mM}$ D-glucose, $2 \% \mathrm{vol} / \mathrm{vol}$, fetal calf serum, and $20 \mathrm{mM}$ HEPES, pH 7.4) at $37^{\circ} \mathrm{C}$ in $5 \% \mathrm{CO}_{2} / 95 \%$ air atmosphere, and the medium was changed every $2 \mathrm{~d}$. Experiments were performed on 
Cell surface Na,K-ATPase

\section{$\alpha$ subunit -}

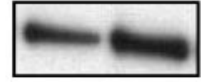

$\left[\mathrm{Na}^{+}\right] \mathbf{m M}$

15135

$\left[\mathrm{Na}^{+}\right] \mathbf{m M}$

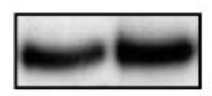

15135
B
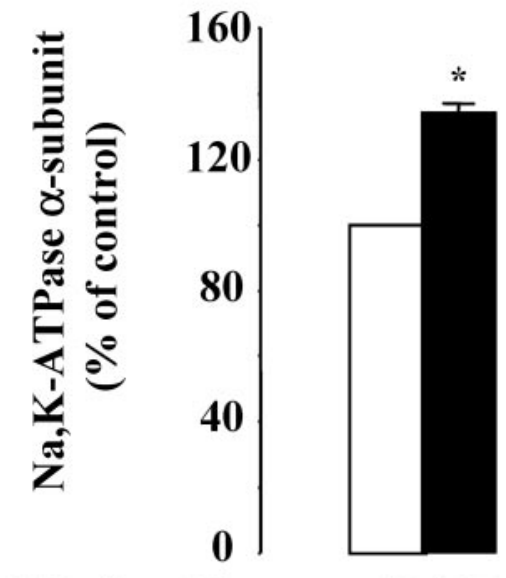

15135

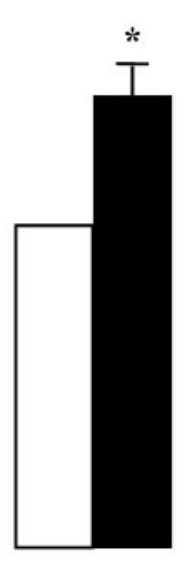

15135

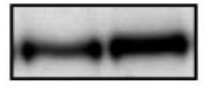

15135
Total Na,K-ATPase

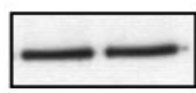

15135

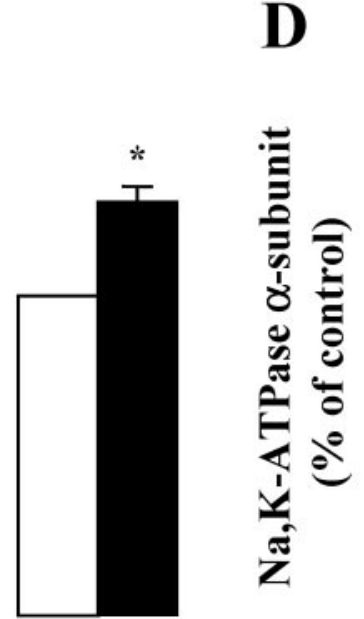

15135
160

120

80

40

0

$\mathrm{K}^{+}$free

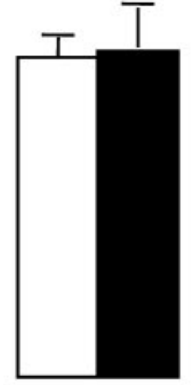

$15 \quad 135$

\section{Amphotericin B}

Nystatin

Figure 2. Effect of high $\left[\mathrm{Na}^{+}\right] \mathrm{i}$ on $\mathrm{Na}, \mathrm{K}-\mathrm{ATPase}$ cell surface and total expression in $\mathrm{mpkCCD}_{\mathrm{c} 14}$ cells. Confluent mpkCCDcl4 cells grown on polycarbonate filters were first preincubated in the presence of 15 or $135 \mathrm{mM} \mathrm{Na}{ }^{+}$for $30 \mathrm{~min}$ at $37^{\circ} \mathrm{C}$ and then permeabilized by $1 \mu \mathrm{g} / \mathrm{ml}$ amphotericin B or $0.1 \mathrm{U} / \mu$ l nystatin, or incubated in $\mathrm{K}^{+}$-free medium for $1 \mathrm{~h}$ at $37^{\circ} \mathrm{C}$. The $\mathrm{Na}$, K-ATPase $\alpha$-subunit was detected by Western blotting performed after biotinylation and streptavidin precipitation of cell surface proteins (Cell surface Na,K-ATPase; A and B) or on cell lysates (Total Na,K-ATPase; C and D). (A and C) Representative immunoblots showing cell surface (A) and total (C) expression of $\mathrm{Na}, \mathrm{K}$-ATPase. (B and D) Bars represent densitometric values expressed as the percentage of the optical density value measured in the presence of $15 \mathrm{mM} \mathrm{Na}^{+}$. Results are means $\pm \mathrm{SE}$ from five independent experiments. ${ }^{*} \mathrm{p}<0.05 \mathrm{vs}$. $15 \mathrm{mM} \mathrm{Na}^{+}$values.

confluent cells seeded on semipermeable polycarbonate filters (Transwell, $0.4-\mu \mathrm{m}$ pore size, $1-\mathrm{cm}^{2}$ growth area, Corning Costar, Cambridge, MA). Cells were kept for 6-8 d in DM medium and then placed in serum-free, hormone-deprived medium $24 \mathrm{~h}$ before the experiments. Except as otherwise noted, the serum-free, hormone-deprived medium was supplemented with $10^{-6} \mathrm{M}$ aldosterone. For experiments, cells were preincubated for $30 \mathrm{~min}$ at $37^{\circ} \mathrm{C}$ with or without drugs in an incubation solution $(5 \mathrm{mM} \mathrm{KCl}$, $1 \mathrm{mM} \mathrm{CaCl}, 1 \mathrm{mM} \mathrm{MgSO}, 0,2 \mathrm{mM} \mathrm{NaH} \mathrm{PO}_{4}, 0.15 \mathrm{mM}$ $\mathrm{Na}_{2} \mathrm{HPO}_{4}, 5 \mathrm{mM}$ glucose, $4 \mathrm{mM} \mathrm{NaHCO}, 12 \mathrm{mM}$ essential amino acids, $2 \mathrm{mM}$ nonessential amino acids, vitamins, $1 \mathrm{mM}$ pyruvic acid, $10 \mathrm{mM}$ lactic acid, $20 \mathrm{mM}$ HEPES, $\mathrm{pH}$ 7.4) supplemented with either $120 \mathrm{mM}$ choline chloride (low- $\mathrm{Na}^{+}$condition; $15 \mathrm{mM}$ $\mathrm{Na}^{+}$) or $120 \mathrm{mM} \mathrm{NaCl}$ (high- $\mathrm{Na}^{+}$condition; $135 \mathrm{mM} \mathrm{Na}^{+}$), with or without drugs. Incubation was carried out for $1 \mathrm{~h}$ at $37^{\circ} \mathrm{C}$ after adding $1 \mu \mathrm{g} / \mathrm{ml}$ amphotericin $\mathrm{B}$ or $0.1 \mathrm{U} / \mathrm{ml}$ nystatin to the basolateral side of the filters. In some cases, experiments were carried out using an incubation solution devoided of $\mathrm{K}^{+}\left(\mathrm{K}^{+}\right.$-free condition).

\section{Measurement of Na,K-ATPase Activity}

The hydrolytic activity of the $\mathrm{Na}, \mathrm{K}-\mathrm{ATPase}$ was determined under $V_{\max }$ conditions by the release of $\mathrm{P}_{\mathrm{i}}$ from $\left[\gamma^{-32} \mathrm{P}\right] \mathrm{ATP}$ (Amersham, United Kingdom) on isolated rat CCDs permeabilized by freeze/ thawing as described (Deschenes and Doucet, 2000). Measurements were performed in quadruplicate on pools of four to six microdissected rat CCDs. The Na,K-ATPase activity was taken as the difference between the means total and $\mathrm{Na}$, K-independent ATPase activities measured in the presence $(100 \mathrm{mM} \mathrm{NaCl}$ and $5 \mathrm{mM} \mathrm{KCl})$ and in the absence of $\mathrm{Na}^{+}$and $\mathrm{K}^{+}(150 \mathrm{mM}$ choline chloride, $2 \mathrm{mM}$ ouabain), respectively. The results were expressed as pmol ATP $\times$ $\mathrm{mm}^{-1} \times \mathrm{h}^{-1}$

\section{Measurement of Total and Cell Surface $\mathrm{Na}, \mathrm{K}$-ATPase}

For measurement of total cellular Na,K-ATPase content, confluent mpkCCD ${ }_{\mathrm{cl} 4}$ cells grown on filters were lysed in homogenizing buffer (HB: 20 mM Tris-HCl, pH 7.4, 2 mM EDTA, 2 mM EGTA, 20 
A

Cell surface Na,K-ATPase

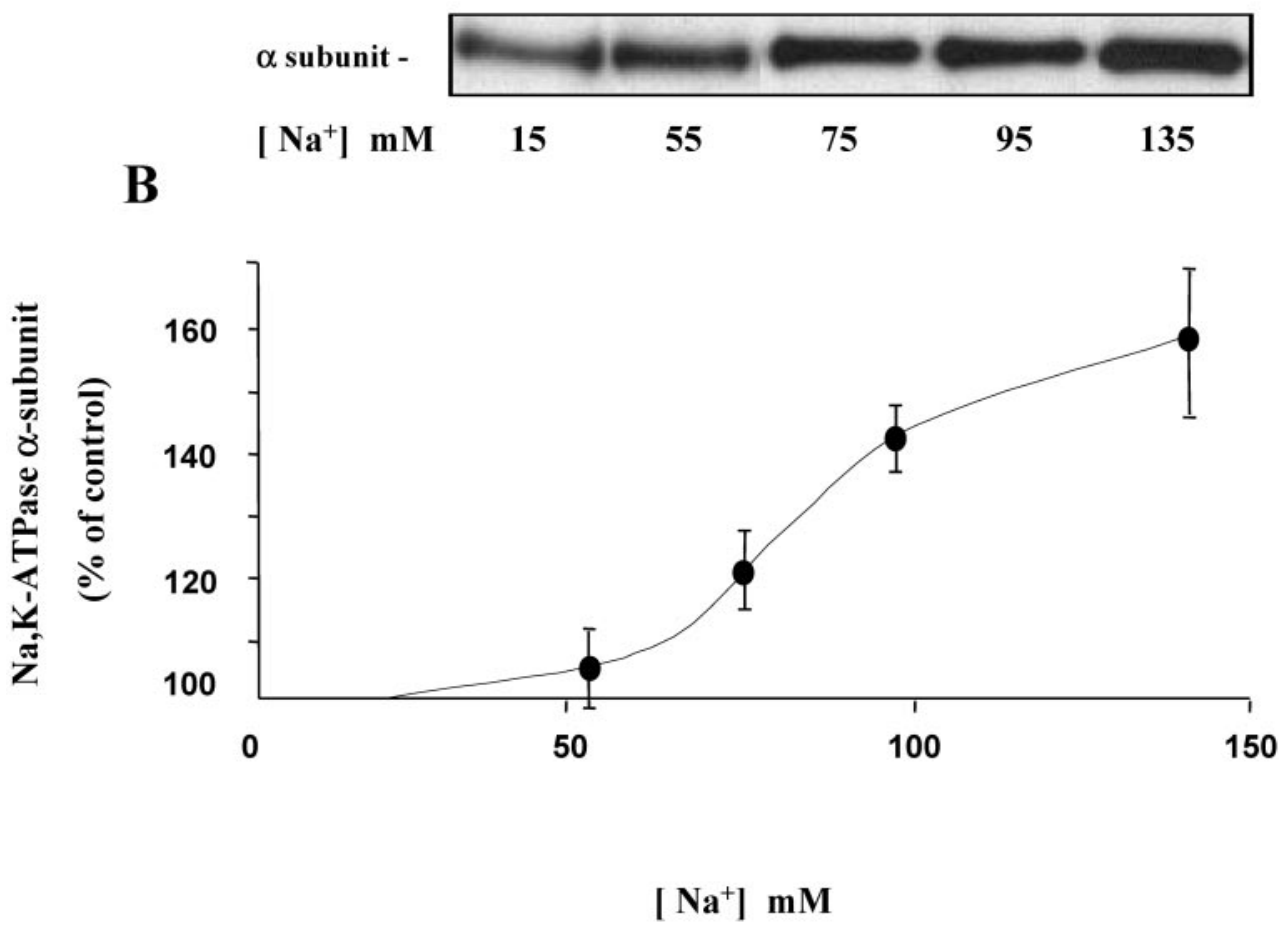

Figure 3. $\left[\mathrm{Na}^{+}\right]$i-dependency of $\mathrm{Na}, \mathrm{K}$-ATPase cell surface expression in $\mathrm{mpkCCD}_{\mathrm{c} 14}$ cells. Amphotericin B-permeabilized mpkCCD ${ }_{\mathrm{cl} 4}$ cells were incubated for $1 \mathrm{~h}$ at $37^{\circ} \mathrm{C}$ in a medium containing increasing concentrations of $\mathrm{Na}^{+}$. Cell surface $\mathrm{Na}, \mathrm{K}-$ ATPase was detected as described in the legend of Figure 2. (A) Representative immunoblots showing $\mathrm{Na}, \mathrm{K}-\mathrm{ATPa} e$ cell surface expression. (B) Densitometric values were expressed as the percentage of the optical density value measured in the presence of $15 \mathrm{mM} \mathrm{Na}^{+}$and plotted against $\mathrm{Na}^{+}$concentration in the medium. Results are means \pm SE from four independent experiments. ${ }^{*} p<0.05$ vs. $15 \mathrm{mM} \mathrm{Na}^{+}$values.

$\mu \mathrm{g} / \mathrm{ml}$ leupeptin, 10 millitrypsin-inhibitor units/ml aprotinin, 30 $\mathrm{mM} \mathrm{NaF}, 30 \mathrm{mM}$ Na pyrophosphate, $1 \mathrm{mM}$ phenylmethylsulfonyl fluoride, $1 \mathrm{mM}$ AEBSF, $0.1 \%$ [wt/vol] SDS, and 1\% [vol/vol] Triton $\mathrm{X}-100)$, and protein content was determined using the BCA assay (Pierce, Rockford, IL). Lysed samples were resuspended in Laemmli's buffer (Laemmli, 1970) and processed for SDS-PAGE. After electrophoresis on $7 \%$ polyacrylamide gels, proteins were electrotransferred to polyvinylidene difluoride membranes (Immobilion-P, Millipore, Waters, MA). Membranes were incubated with a polyclonal antibody (dilution $1 / 10,000$ ) raised against the $\alpha$-subunit of Na,K-ATPase (Carranza et al., 1996a) in Tris-buffered saline (TBS) NP-40 (150 mM NaCl, $50 \mathrm{mM}$ Tris, $0.2 \%$ NP-40, pH 7.4) with 5\% (wt/vol) nonfat dried milk. After washing, membranes were incubated with an anti-rabbit IgG antibody (dilution 1/10,000) coupled to horseradish peroxidase (BD Transduction Laboratories, San Diego, CA). The antigen-antibody complexes were detected by chemiluminescence with the Super Signal Substrate method (Pierce) according to the manufacturer's instructions. The protein bands revealed were quantified using a video densitometer and ImageQuant software (Molecular Dynamics, Sunnyvalle, CA), and the results were expressed as percent of the intensity of the protein band from control samples.

Measurements of cell surface Na,K-ATPase were performed on isolated rat CCDs and cultured mpkCCD $\mathrm{cl}_{4}$ cells as described (Gonin et al., 2001) using EZ-Link sulfosuccinimidobiotin (Sulfo NHSS-S-Biotin, Pierce) to label cell surface proteins. After lysis in HB buffer, equal amounts of protein were precipitated in the presence of streptavidin-agarose beads (Immunopure immobilized streptavidin, Pierce) diluted in an antiprotease-supplemented buffer solution (TLB: $50 \mathrm{mM}$ Tris- $\mathrm{HCl}, \mathrm{pH}$ 7.4, $100 \mathrm{mM} \mathrm{NaCl}, 5 \mathrm{mM}$ EDTA, 20 $\mu \mathrm{g} / \mathrm{ml}$ leupeptin, $1 \mu \mathrm{g} / \mathrm{ml}$ aprotinin). The beads were then washed three times with the TLB solution and once with $10 \mathrm{mM}$ Tris- $\mathrm{HCl}$, $\mathrm{pH}$ 7.4. After resuspension in Laemmli's buffer (Laemmli, 1970), samples were processed for SDS-PAGE and Western blotting as described above.

\section{Measurement of Intracellular cAMP Content}

After incubation under various experimental conditions, the cAMP content of individual microdissected rat CCDs was measured using a previously described radioimmunoassay (Chabardès et al., 1984). Results were expressed as fmol cAMP $\times \mathrm{mm}^{-1}$.

Confluent $\mathrm{mpkCCD} \mathrm{cl}_{4}$ cells grown on filters under various experimental conditions were scraped off the filters and homogenized in a buffer containing $50 \mathrm{mM}$ Tris, $4 \mathrm{mM}$ EDTA, $\mathrm{pH}$ 7.4. IBM-X $\left(10^{-5}\right.$ $\mathrm{M})$ was added during the incubation period and in the homogenization buffer to prevent cAMP degradation by phosphodiesterases. Cellular cAMP levels were then measured using the cyclic AMP $\left({ }^{3} \mathrm{H}\right)$ system (Amersham, United Kingdom) according to the manufacturer's instructions. Results were expressed as a pmol cAMP $\times$ $\mu \mathrm{g}$ protein $^{-1}$.

\section{Measurement of PKA Activity}

Confluent mpkCCD $\mathrm{pl}_{4}$ cells grown on filters and incubated under various experimental conditions were scraped off and homogenized in an extraction buffer ( $25 \mathrm{mM}$ Tris- $\mathrm{HCl}, \mathrm{pH} 7.4,0.5 \mathrm{mM}$ EDTA, 0.5 $\mathrm{mM}$ EGTA, $10 \mathrm{mM} \beta$-mercaptoethanol, $1 \mu \mathrm{g} / \mathrm{ml}$ leupeptin, and 1 $\mu \mathrm{g} / \mathrm{ml}$ aprotinin). Protein Kinase A activity was then measured using the SignaTECT ${ }^{\mathrm{R}}$ cAMP-Dependent Protein Kinase (PKA) Assay System (Promega, Madison, WI) according to the manufacturer's instructions. Results were expressed as pmol ATP $\times \min ^{-1} \times$ $\mu \mathrm{g}$ protein $^{-1}$.

\section{Statistics}

Results are given as the mean \pm SE from (n) independent experiments. Each experiment was performed on microdissected tubules from the same animal or on cultured cells from the same passage. Statistical differences in Na,K-ATPase activity, PKA activity, and cellular cAMP content measured under various conditions were 
Figure 4. Effect of transcription and translation inhibition on $\left[\mathrm{Na}^{+}\right] \mathrm{i}-$ dependent $\mathrm{Na}$,K-ATPase cell surface expression in $\mathrm{mpkCCD}_{\mathrm{cl}}$ cells. Confluent mpkCCDcl4 cells grown on polycarbonate filters were first preincubated in the presence of $15 \mathrm{mM}$ or $135 \mathrm{mM} \mathrm{Na}^{+}$without $(-)$or with (+) $5 \mu \mathrm{M}$ actinomycin D (Act; A and C) or $20 \mu \mathrm{M}$ cycloheximide (Суc; B and D) for $30 \mathrm{~min}$ at $37^{\circ} \mathrm{C}$. After permeabilization by $1 \mu \mathrm{g} / \mathrm{ml}$ amphotericin B cells were incubated for $1 \mathrm{~h}$ at $37^{\circ} \mathrm{C}$. Cell surface $\mathrm{Na}, \mathrm{K}-\mathrm{ATPase}$ was detected as described in the legend of Figure 2. (A and B) Representative immunoblots showing $\mathrm{Na}, \mathrm{K}-\mathrm{AT}$ Pase cell surface expression. (C and D) Bars represent densitometric values expressed as the percentage of the optical density value measured in the presence of $15 \mathrm{mM} \mathrm{Na}^{+}$. Results are means \pm SE from six independent experiments. ${ }^{*} \mathrm{p}<0.05$ vs. $15 \mathrm{mM} \mathrm{Na}^{+}$values.
A

$$
\alpha \text { subunit - }
$$

$\left[\mathrm{Na}^{+}\right] \mathrm{mM}$

\section{Cell surface Na,K-ATPase}

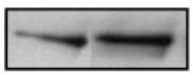

15135

- ACT

C

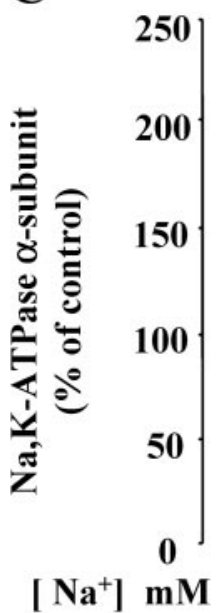

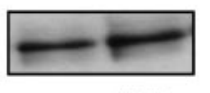

15135

$+\mathrm{ACT}$

D
B

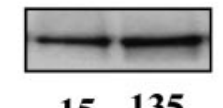

15135

- CYC

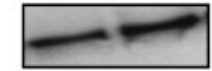

15135

$+\mathrm{CYC}$

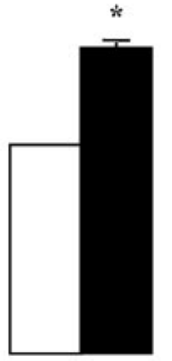

15135

- CYC

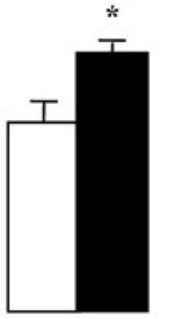

15135

$+\mathrm{CYC}$ done using the unpaired Student $t$ test or by analysis of variance for comparison of two or more than two groups, respectively. Statistical analysis of $\mathrm{Na}$, K-ATPase $\alpha$-subunit immunoreactivity was done using the Mann-Whitney $U$ test or the Kruskal-Wallis test for comparison of two or more than two groups, respectively. $p<0.05$ was considered significant.

\section{RESULTS}

\section{Rising Intracellular $\mathrm{Na}^{+}$Content Increases $\mathrm{Na}, \mathrm{K}$ - ATPase Cell Surface Expression in Intact Rat CCDs and in Mouse mpkCCD ${ }_{\text {clu }}$ Cells}

We first assessed the consequences of increased $\left[\mathrm{Na}^{+}\right] \mathrm{i}$ on $\mathrm{Na}, \mathrm{K}-\mathrm{ATPase}$ activity, and cell surface expression. $\left[\mathrm{Na}^{+}\right] \mathrm{i}$ was increased by incubating isolated rat CCDs with the $\mathrm{Na}^{+}$ ionophore nystatin $(0.1 \mathrm{U} / \mu \mathrm{l})$ for $2 \mathrm{~h}$ at $37^{\circ} \mathrm{C}$. Figure 1 shows that nystatin induced a significant increase in both $\mathrm{Na}, \mathrm{K}$ ATPase activity measured at $V_{\max }$ (as percentage of control $\pm \mathrm{SE} ; 191 \pm 14 \% ; \mathrm{n}=5 ; \mathrm{p}<0.05$ ) and $\mathrm{Na}, \mathrm{K}-\mathrm{ATPase}$ cell surface expression (as percentage of control \pm SE; $181 \pm$ $40 \% ; \mathrm{n}=10 ; \mathrm{p}<0.05)$. These results indicate that the increased levels of $\left[\mathrm{Na}^{+}\right]$i increased maximal $\mathrm{Na}, \mathrm{K}$-ATPase activity and Na-pump cell surface expression to the same extent in rat CCD.

Similar experiments were performed in confluent mpkCCDcl4 cells grown on filters and incubated with high $(135 \mathrm{mM})$ or low $(15 \mathrm{mM}) \mathrm{Na}^{+}$solutions. In this case, cultured cells were incubated with two different $\mathrm{Na}^{+}$ionophores, nystatin $(0.1 \mathrm{U} / \mu \mathrm{l})$ or amphotericin B $(1 \mu \mathrm{g} / \mathrm{ml})$, in order to enhance plasma membrane permeability to $\mathrm{Na}^{+}$ and to decrease the concentration gradient between intracellular and extracellular $\mathrm{Na}^{+}$. Experiments were also per- formed using a $\mathrm{K}^{+}$free solution, which reversibly inhibits $\mathrm{Na}, \mathrm{K}-\mathrm{ATPase}$ and therefore disrupts the physiological $\mathrm{Na}^{+}$ concentration gradient across the plasma membrane (BlotChabaud et al., 1990). Under these conditions, $\mathrm{mpkCCD}_{\mathrm{c} 14}$ cells incubated in a solution containing $135 \mathrm{mM} \mathrm{Na}^{+}$in order to increase $\left[\mathrm{Na}^{+}\right] \mathrm{i}$, exhibited a greater cell surface expression of $\mathrm{Na}, \mathrm{K}$-ATPase as compared with the same set of cells incubated in a solution containing $15 \mathrm{mM} \mathrm{Na}^{+}$ (Figure 2, A and B). The increase in Na,K-ATPase cell surface expression occurred after a lag time of $30 \mathrm{~min}$ and was maximal after 1-h incubation at $37^{\circ} \mathrm{C}$ (our unpublished results). In contrast, a rise in $\left[\mathrm{Na}^{+}\right]$i did not alter $\mathrm{Na}, \mathrm{K}$-ATPase total cellular content (Figure 2, C and D). A graded increase in $\left[\mathrm{Na}^{+}\right]$e from $15-135 \mathrm{mM}$ produced a $\mathrm{Na}^{+}$concentrationdependent increase in $\mathrm{Na}, \mathrm{K}-\mathrm{ATP}$ ase cell surface expression in amphotericin B-permeabilized $\mathrm{mpkCCD}_{\mathrm{cl} 4}$ cells (Figure 3). Control experiments were performed to assess the effect of amphotericin B permeabilization on $\mathrm{mpkCCD}_{\mathrm{c14}}$ cell viability. Addition of $10^{-9} \mathrm{M}$ vasopressin during the last 10 min of the 1-h incubation in the presence of amphotericin B produced a close to sixfold increase in cellular cAMP content (see Figure 7) indicating that cellular ATP content was not depleted by ionophore treatment. In addition, although transepithelial resistance and potential fell to zero in amphotericin B permeabilized confluent cells, a full recovery was observed $24 \mathrm{~h}$ after ionophore washout. Moreover, addition of vasopressin $\left(10^{-9} \mathrm{M}\right)$ for $24 \mathrm{~h}$ after ionophore washout decreased transepithelial resistance from $4928 \pm 142$ to $3500 \pm 214$ Omhs $/ \mathrm{cm}^{2}(\mathrm{n}=4)$, increased transepithelial potential from $41 \pm 2$ to $53 \pm 2 \mathrm{mV}$ and induced aquaporin-2 water channel expression (our unpublished results), as previously described in nonpermeabilized cells (Vandewalle et 
A

\section{Cell surface Na,K-ATPase}

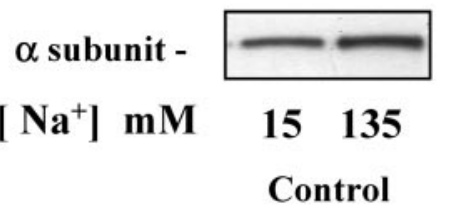

B

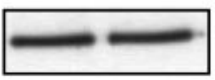

15135

H7

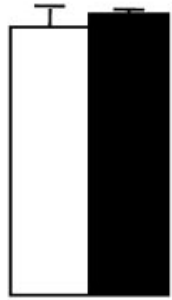

15135
15135

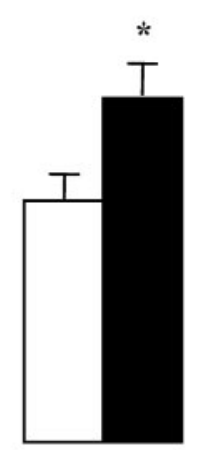

Control
H7
GF

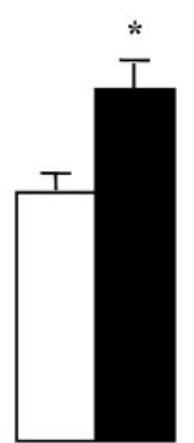

15135

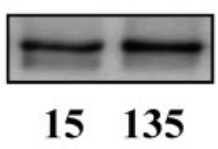

ML-7

Figure 5. Effect of serine/threonine kinase inhibitors on the $\left[\mathrm{Na}^{+}\right] \mathrm{i}-$ dependent $\mathrm{Na}$,K-ATPase cell surface expression in $\mathrm{mpkCCD}_{\mathrm{cl} 4}$ cells. Confluent mpkCCDcl4 cells grown on polycarbonate filters were first preincubated in the presence of 15 or 135 $\mathrm{mM} \mathrm{Na}{ }^{+}$without or with $10^{-5} \mathrm{M}$ H-7, 10-6 M GF109203X (GF), or $10^{-5} \mathrm{M} \mathrm{ML}-7$ for $30 \mathrm{~min}$ at $37^{\circ} \mathrm{C}$. After permeabilization by $1 \mu \mathrm{g} / \mathrm{ml}$ amphotericin $\mathrm{B}$ cells were incubated for $1 \mathrm{~h}$ at $37^{\circ} \mathrm{C}$. Cell surface $\mathrm{Na}, \mathrm{K}-$ ATPase was detected as described in the legend of Figure 2. (A) Representative immunoblot showing $\mathrm{Na}$, $\mathrm{K}$ ATPase cell surface expression. (B) Bars represent densitometric values expressed as the percentage of the optical density value measured in the presence of $15 \mathrm{mM} \mathrm{Na}{ }^{+}$. Results are means $\pm \mathrm{SE}$ from six independent experiments. ${ }^{*} \mathrm{p}<0.05$ vs. 15 $\mathrm{mM} \mathrm{Na}^{+}$values. al., 1999; Hasler et al., 2002). Therefore, short-term (1 h) amphotericin B permeabilization did not significantly alter the viability and vasopressin responsiveness of mpkCCDcl4 cells. These results indicate that cultured mpkCCD ${ }_{\mathrm{cl} 4}$ cells represent a suitable ex vivo cell system for extensive analysis of mechanism(s) underlying the $\mathrm{Na}, \mathrm{K}-\mathrm{ATPase}$ recruitment to the cell surface in response to high $\left[\mathrm{Na}^{+}\right]$i.

\section{The Increase in Na,K-ATPase Cell Surface Expression Induced by a Rise in $\left[\mathrm{Na}^{+}\right]$i Is Enhanced by Corticosteroids and Independent of Ongoing Transcription and De Novo Translation}

The recruitment of active $\mathrm{Na}, \mathrm{K}$-ATPase units induced by a rise in $\left[\mathrm{Na}^{+}\right] \mathrm{i}$ has been shown to require the presence of aldosterone in isolated mammalian CCDs (Barlet Bas et al., 1990; Blot-Chabaud et al., 1990). Experiments were performed on confluent mpkCCD ${ }_{\mathrm{c} 14}$ cells grown in serum-free, hormone-deprived medium and in the absence or presence of $10^{-6} \mathrm{M}$ aldosterone for $72 \mathrm{~h}$ to assess the aldosteronedependency of $\left[\mathrm{Na}^{+}\right]$i-induced increase in cell surface expression of $\mathrm{Na}, \mathrm{K}-\mathrm{ATPase}$. The $\left[\mathrm{Na}^{+}\right] \mathrm{i}$-dependent increase in $\mathrm{Na}, \mathrm{K}-\mathrm{ATPase}$ cell surface expression measured on amphotericin B-permeabilized cells was significantly reduced in mpkCCD ${ }_{\mathrm{c} 14}$ cells grown in hormone-free medium (as percentage of control $\pm \mathrm{SE} ; 111 \pm 1.6 \%$ ) compared with aldosterone-treated cells (as percentage of control $\pm \mathrm{SE} ; 126 \pm$ $0.3 ; \mathrm{n}=6$; $\mathrm{p}<0.05$; our unpublished results). Therefore, these results indicate that corticosteroid hormones potenti- ate $\mathrm{Na}, \mathrm{K}$-ATPase cell membrane recruitment caused by a rise in $\left[\mathrm{Na}^{+}\right] \mathrm{i}$ in $\mathrm{mpkCCD}_{\mathrm{cl} 4}$ cells.

Because the time course of $\left[\mathrm{Na}^{+}\right] \mathrm{i}$-induced recruitment of $\mathrm{Na}, \mathrm{K}-\mathrm{ATPase}$ units to the cell surface (30-60 min) is compatible with de novo protein synthesis, we assessed the effects of actinomycin D and cycloheximide, two classical inhibitors of transcription and protein synthesis, respectively. In amphotericin B-permeabilized cells, neither $5 \mu \mathrm{M}$ actinomycin D nor $20 \mu \mathrm{M}$ cycloheximide prevented the effect of $\left[\mathrm{Na}^{+}\right] \mathrm{i}$ on $\mathrm{Na}, \mathrm{K}-\mathrm{ATP}$ ase cell surface expression (Figure 4). These results indicate that recruitment of $\mathrm{Na}, \mathrm{K}-$ ATPase by a rise in $\left[\mathrm{Na}^{+}\right]$i does not rely on transcriptional activity or on de novo protein synthesis.

\section{The $\left[\mathrm{Na}^{+}\right] \mathrm{i}$-dependent Increase of $\mathrm{Na}, \mathrm{K}-\mathrm{ATPa}$ a Cell Surface Expression Relies on PKA Activation}

We next examined the involvement of serine/threonine kinase in $\left[\mathrm{Na}^{+}\right] \mathrm{i}$-dependent $\mathrm{Na}, \mathrm{K}$-ATPase cell surface expression. In amphotericin B-permeabilized mpkCCD ${ }_{\mathrm{cl} 4}$ cells incubated in low- or high- $\mathrm{Na}^{+}$media, the broad-range serine/ threonine kinases inhibitor $\mathrm{H}-7 \quad\left(10^{-5} \mathrm{M}\right)$ abolished the $\left[\mathrm{Na}^{+}\right] \mathrm{i}$-dependent increase of $\mathrm{Na}, \mathrm{K}-\mathrm{ATPa} e$ cell surface expression (Figure 5).

We next refined our analysis of protein kinases involved in the $\left[\mathrm{Na}^{+}\right] \mathrm{i}$-induced upregulation of cell surface-expressed $\mathrm{Na}, \mathrm{K}-\mathrm{ATP}$ ase by investigating the effects of various narrowrange serine/threonine kinase inhibitors. The results obtained indicate that neither GF109203X $\left(10^{-6} \mathrm{M}\right)$, a protein 
A

Cell surface Na,K-ATPase
C

E

Cell surface $\mathrm{Na}, \mathrm{K}-\mathrm{ATPase}$

Cell surface Na,K-ATPase $\alpha$ subunit -

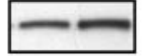

$\left[\mathrm{Na}^{+}\right] \mathrm{mM}$

15135

Control

B

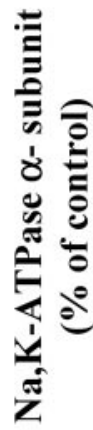

$\left[\mathrm{Na}^{+}\right] \mathbf{m M}$

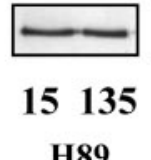

H89

\begin{abstract}
D
\end{abstract}
D

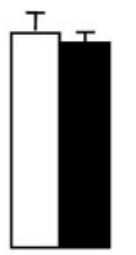

15135

Control

H89 $\alpha$ subunit -
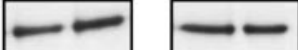

15135

Control

15135
PKI

$\alpha$ subunit -

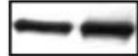

$\left[\mathrm{Na}^{+}\right] \mathbf{m M}$

15135

Control F

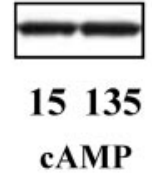

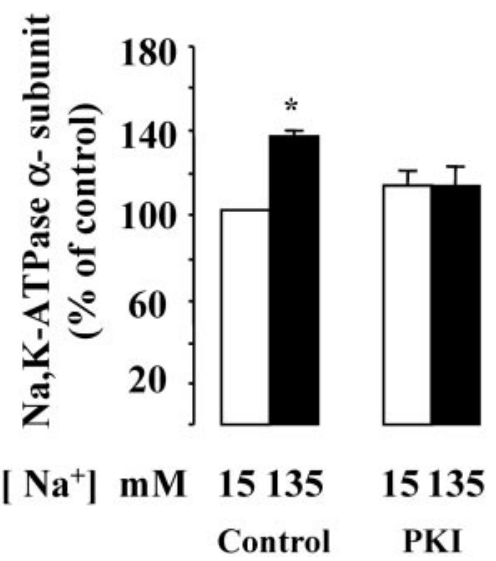
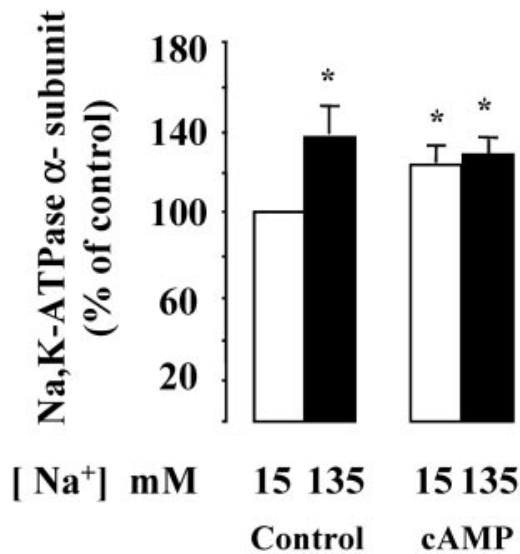

15135

15135
Control

cAMP

Figure 6. Effect of PKA inhibition and activation on $\left[\mathrm{Na}^{+}\right] \mathrm{i}$-dependent $\mathrm{Na}, \mathrm{K}-\mathrm{ATPase}$ cell surface expression of in $\mathrm{mpkCCD}_{\mathrm{cl} 4}$ cells and $\mathrm{Na}$,K-ATPase activity in isolated rat CCDs. (A and B) Confluent mpkCCDcl4 cells grown on polycarbonate filters were first preincubated in the presence of either 15 or $135 \mathrm{mM} \mathrm{Na}^{+}$without or with $5 \times 10^{-5} \mathrm{M} \mathrm{H}-89$ for $30 \mathrm{~min}$ at $37^{\circ} \mathrm{C}$. After permeabilization by $1 \mu \mathrm{g} / \mathrm{ml}$ amphotericin B, cells were incubated for $1 \mathrm{~h}$ at $37^{\circ} \mathrm{C}$. Cell surface $\mathrm{Na}, \mathrm{K}$-ATPase was detected as described in the legend of Figure 2. (A) Representative immunoblot showing Na,K-ATPase cell surface expression. (B) Bars represent densitometric values expressed as the percentage of the optical density value measured in the presence of $15 \mathrm{mM} \mathrm{Na}^{+}$. Results are means \pm SE from four independent experiments. ${ }^{*} \mathrm{p}<0.05$ vs. $15 \mathrm{mM} \mathrm{Na}^{+}$values. (C and D) Confluent mpkCCDcl4 cells grown on polycarbonate filters were first preincubated in the presence of either 15 or $135 \mathrm{mM} \mathrm{Na}^{+}$without or with $50 \mu \mathrm{M}$ myristoylated PKI for $30 \mathrm{~min}$ at $37^{\circ} \mathrm{C}$. After permeabilization by $1 \mu \mathrm{g} / \mathrm{ml}$ amphotericin $\mathrm{B}$, cells were incubated for $1 \mathrm{~h}$ at $37^{\circ} \mathrm{C}$. Cell surface Na,K-ATPase was detected as described in the legend of Figure 2. (A) Representative immunoblot showing Na,K-ATPase cell surface expression. (B) Bars represent densitometric values expressed as the percentage of the optical density value measured in the presence of $15 \mathrm{mM} \mathrm{Na}^{+}$. Results are means \pm SE from four independent experiments. ${ }^{*} \mathrm{p}<0.05 \mathrm{vs}$. $15 \mathrm{mM}$ $\mathrm{Na}^{+}$values. (E and F) Confluent mpkCCDcl4 cells grown on polycarbonate filters were first preincubated in the presence of 15 or $135 \mathrm{mM}$ $\mathrm{Na}^{+}$for $30 \mathrm{~min}$ at $37^{\circ} \mathrm{C}$. After permeabilization by $1 \mu \mathrm{g} / \mathrm{ml}$ amphotericin $\mathrm{B}$, cells were incubated for $1 \mathrm{~h}$ at $37^{\circ} \mathrm{C}$ and $10^{-3} \mathrm{M} \mathrm{db}-\mathrm{cAMP}$ was added or not for the last $10 \mathrm{~min}$ of incubation. Cell surface Na,K-ATPase was detected as described in the legend of Figure 2. (D) Representative immunoblot showing Na,K-ATPase cell surface expression. (E) Bars represent densitometric values expressed as the percentage of the optical density value measured in the presence of $15 \mathrm{mM} \mathrm{Na}^{+}$. Results are means \pm SE from four independent experiments. ${ }^{*} \mathrm{p}<0.05$ vs. $15 \mathrm{mM} \mathrm{Na}{ }^{+}$values.

kinase C inhibitor, nor ML-7 $\left(10^{-5} \mathrm{M}\right)$, a myosin light chain kinase inhibitor, altered the stimulatory effect of increased $\left[\mathrm{Na}^{+}\right]$i on cell surface expression of $\mathrm{Na}, \mathrm{K}-\mathrm{ATPase}$ (Figure 5). In contrast, H89 $\left(5 \times 10^{-5} \mathrm{M}\right)$, a preferential but not fully specific protein kinase A (PKA) inhibitor (Davies et al., 2000), prevented the $\left[\mathrm{Na}^{+}\right] \mathrm{i}$-dependent recruitment of $\mathrm{Na}, \mathrm{K}-$ ATPase to the cell surface of mpkCCD ${ }_{\mathrm{cl} 4}$ cells (Figure 6, A and B). Figure 6, C and D, shows that $50 \mu \mathrm{M}$ myristoylated PKI, a cell-permeable peptide inhibitor of PKA, also prevented the effect of increased $\left[\mathrm{Na}^{+}\right] \mathrm{i}$ on cell surface expression of $\mathrm{Na}, \mathrm{K}$-ATPase. In addition, H89 also abolished the increase of $\mathrm{Na}, \mathrm{K}$-ATPase activity induced by nystatin in isolated rat CCDs (as pmol $\times \mathrm{mm}^{-1} \times \mathrm{h}^{-1} \pm \mathrm{SE}$; Control: $501 \pm 83$; Nystatin: $844 \pm 64^{*}$; H89: $570 \pm 40$; H89 + Nystatin: $569 \pm 21 ; \mathrm{n}=4^{*} ; \mathrm{p}<0.05$ vs. control). Because we have previously shown that cAMP, a classical PKA activator, induced the translocation of an intracellular pool of
$\mathrm{Na}, \mathrm{K}-\mathrm{ATP}$ ase to the plasma membrane (Gonin et al., 2001), we studied the additivity of Na,K-ATPase cell surface expression induced by both $\left[\mathrm{Na}^{+}\right] \mathrm{i}$ and cAMP. In amphotericin B-permeabilized mpkCCD $\mathrm{cl}_{4}$ cells incubated in a low $\mathrm{Na}^{+}(15 \mathrm{mM})$ solution, addition of db-cAMP $\left(10^{-3} \mathrm{M}\right)$, a cell-permeant cAMP analog, for $10 \mathrm{~min}$ at $37^{\circ} \mathrm{C}$ increased $\mathrm{Na}, \mathrm{K}-\mathrm{ATPase}$ cell surface expression by $25 \pm 5 \%$. In contrast, db-cAMP did not further increase $\mathrm{Na}, \mathrm{K}$-ATPase cell surface expression in amphotericin B-permeabilized cells incubated in a high- $\mathrm{Na}^{+}(135 \mathrm{mM})$ solution (Figure 6, E and F). These results strongly suggest that PKA activity is stimulated by a rise in $\left[\mathrm{Na}^{+}\right]$i.

To further confirm that the stimulatory effect of high $\left[\mathrm{Na}^{+}\right] \mathrm{i}$ on $\mathrm{Na}, \mathrm{K}-\mathrm{ATPase}$ cell surface expression was dependent on PKA activation, PKA activity was measured in amphotericin B-permeabilized mpkCCD ${ }_{\mathrm{cl} 4}$ cells. As shown in Figure 7A, incubation of permeabilized cells for 30-60 
A

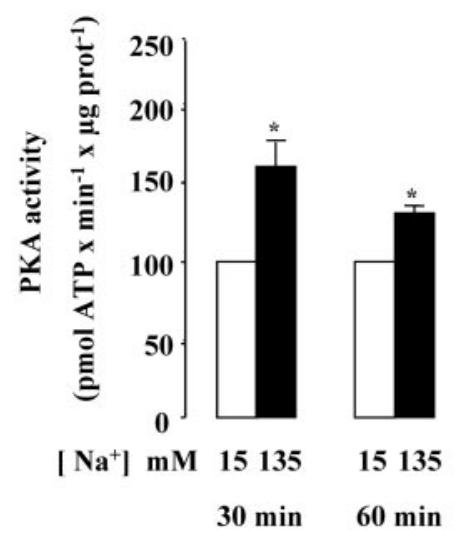

B

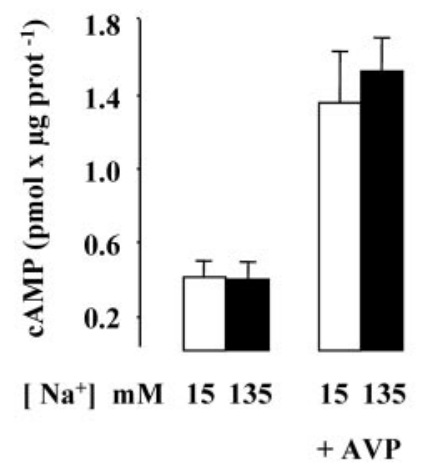

C

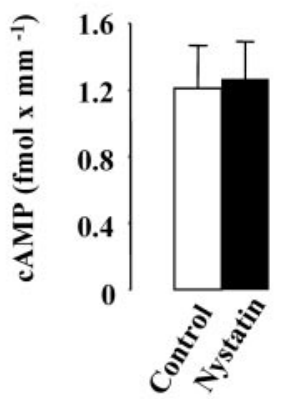

Figure 7. Effect of high $\left[\mathrm{Na}^{+}\right] \mathrm{i}$ on PKA activity in mpkCCD ${ }_{\text {c14 }}$ cells and cellular cAMP content in mpkC$\mathrm{CD}_{\mathrm{c} 14}$ cells and isolated rat CCDs. (A and B) Confluent mpkCCDcl4 cells grown on polycarbonate filters were first preincubated in the presence of 15 or $135 \mathrm{mM} \mathrm{Na}^{+}$for $30 \mathrm{~min}$ at $37^{\circ} \mathrm{C}$. (A) After permeabilization by $1 \mu \mathrm{g} / \mathrm{ml}$ amphotericin B, cells were incubated for $30-60 \mathrm{~min}$ at $37^{\circ} \mathrm{C}$. The PKA activity was measured on homogenized cells using the SignaTECT cAMP-dependent Protein Kinase Assay System as described in MATERIALS AND METHODS. Results expressed as pmol ATP $\times$ $\min ^{-1} \times \mu$ g protein ${ }^{-1}$ are means \pm $\mathrm{SE}$ from four independent experiments. ${ }^{*} \mathrm{p}<0.05$ vs. $15 \mathrm{mM} \mathrm{Na}{ }^{+}$values. (B) After permeabilization by 1 $\mu \mathrm{g} / \mathrm{ml}$ amphotericin $\mathrm{B}$, cells were incubated for $60 \mathrm{~min}$ at $37^{\circ} \mathrm{C}$ and $10^{-9}$
lar cAMP content was measured on $\mathrm{M}$ vasopressin (AVP) was added or not to the cell medium during the last $10 \mathrm{~min}$ of incubation. The cellular cAMP content was measured on
homogenized cells using the cyclic AMP $\left({ }^{3} \mathrm{H}\right)$ assay system as described in MATERIALS AND METHODS. Results expressed as pmol cAMP $\times \mu$ g protein $^{-1}$ are means $\pm \mathrm{SE}$ from four independent experiments. (C) Microdissected CCDs were incubated in the absence (control) or presence of $0.1 \mathrm{U} / \mu \mathrm{l}$ nystatin for $1 \mathrm{~h}$ at $37^{\circ} \mathrm{C}$. Cellular cAMP content was determined using a radioimmunoassay as described in MATERIAL AND METHODS. Results expressed as fmol cAMP $\times \mathrm{mm}^{-1}$ are means $\pm \mathrm{SE}$ from six animals. min at $37^{\circ} \mathrm{C}$ in the presence of $135 \mathrm{mM} \mathrm{Na}^{+}$induced a sustained increase in PKA activity. Because PKA activation is classically related to an increase in cellular cAMP content, cellular cAMP content was measured in amphotericin B-permeabilized mpkCCD ${ }_{\text {c14 }}$ cells. Unexpectedly, the amount of cellular cAMP content did not change in cells incubated in mediums containing either $15 \mathrm{mM}$ or $135 \mathrm{mM}$ $\mathrm{Na}^{+}$(Figure 7B). Similarly, increasing $\left[\mathrm{Na}^{+}\right] \mathrm{i}_{\mathrm{i}}$ did not alter the cAMP content of cells preincubated with the phosphodiesterase inhibitor IBMX $\left(10^{-4} \mathrm{M}\right.$; our unpublished results). In contrast, $10^{-9} \mathrm{M}$ vasopressin, a classical adenylate cyclase activator, added during the last $10 \mathrm{~min}$ of incubation, induced a large increase in cellular cAMP content in amphoterincin B-permeabilized cells (Figure 7B). This AVP-induced increase in cellular cAMP content was not influenced by increased $\left[\mathrm{Na}^{+}\right]$i. Therefore, amphotericin B permeabilization did not induce a large leak of cAMP out of mpkCCDcl4 cells and increasing $\left[\mathrm{Na}^{+}\right] \mathrm{i}$ did not alter the adenylate cyclase responsiveness to AVP. Furthermore, cellular cAMP content was not altered in nystatin-permeabilized isolated rat CCDs (Figure 7C). Altogether, these results indicate that a rise in $\left[\mathrm{Na}^{+}\right] \mathrm{i}$ induces PKA activation independently of any detectable increase in cellular cAMP content.

\section{Inhibitors of the Proteasomal Degradation Pathway Prevent $\left[\mathrm{Na}^{+}\right]$i-induced PKA Activation and Increase in Na,K-ATPase Cell Surface Expression}

It has been reported that cytokines may trigger cAMP-independent activation of PKA (Zhong et al., 1997) through a pathway that requires proteasomal activity (Dulin et al., 2001). Experiments were performed to investigate the possible roles of the proteasomal and lysosomal protein degradation pathways in $\mathrm{Na}, \mathrm{K}-\mathrm{ATPa} e$ recruitment to the $\mathrm{mpkCCD}_{\mathrm{cl} 4}$ cell surface induced by a rise $\left[\mathrm{Na}^{+}\right]$i. Proteaso- mal activity was inhibited by addition of $10^{-6}$ M MG132 or lactacystin, two specific and structurally unrelated proteasome inhibitors. To analyze the contribution of the lysosome, we used either $2 \times 10^{-6} \mathrm{M}$ leupeptin, an inhibitor of cysteine proteases, or $10^{-7} \mathrm{M}$ chloroquine, a weak base that increases lysosomal $\mathrm{pH}$ and thereby inhibits the proteolytic activity of lysosomal enzymes. We first checked that these drugs did not modify the high transepithelial electrical resistance of confluent mpkCCD ${ }_{\mathrm{C} 14}$ cells (our unpublished results). Figure 8 shows that the presence of proteasomal inhibitors completely abolished the $\left[\mathrm{Na}^{+}\right] \mathrm{i}$-induced increase of $\mathrm{Na}, \mathrm{K}-\mathrm{ATPase}$ expressed at the cell surface and blocked the stimulation of PKA activity in amphotericin B-permeabilized mpkCCD $\mathrm{cl}_{4}$ cells. In contrast, none of the lysosomal inhibitors used altered the increase in $\mathrm{Na}, \mathrm{K}$-ATPase cell surface expression caused by a rise in $\left[\mathrm{Na}^{+}\right]$i (Figure 9). These results indicate that the proteasomal but not the lysosomal degradation pathway is involved in $\left[\mathrm{Na}^{+}\right] \mathrm{i}$-dependent recruitment of $\mathrm{Na}, \mathrm{K}-\mathrm{ATPase}$ to the cell surface of mpkCCD ${ }_{\mathrm{cl} 4}$ cells.

\section{DISCUSSION}

This study provides several lines of evidence that 1) translocation of an intracellular reservoir of Na-pumps to the plasma membrane is responsible for the stimulation of $\mathrm{Na}, \mathrm{K}-\mathrm{ATPase}$ activity observed in response to an increase in $\left[\mathrm{Na}^{+}\right] \mathrm{i}$ in mammalian CCD principal cells and 2) this recruitment of $\mathrm{Na}, \mathrm{K}$-ATPase units is at least in part mediated by cAMP-independent PKA activation and requires the proteasomal degradation of a yet unidentified regulatory factor that maintains PKAc in an inactive state.

$\left[\mathrm{Na}^{+}\right] \mathrm{i}$, aldosterone, and vasopressin (Gonin et al., 2001; Summa et al., 2001) all control $\mathrm{Na}, \mathrm{K}-\mathrm{ATPase}$ cell surface 


\section{Cell surface Na,K-ATPase}

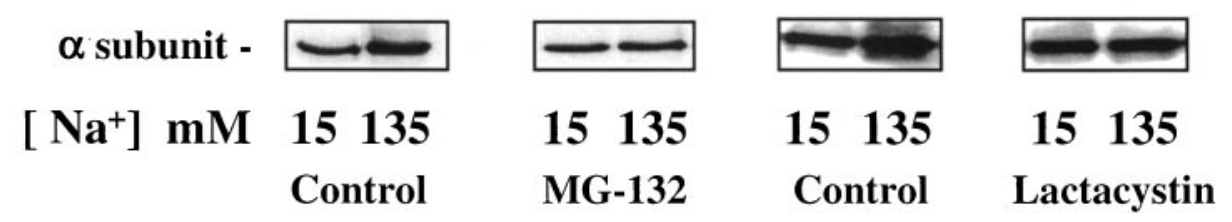

Figure 8. Effect of proteasomal inhibitors on $\left[\mathrm{Na}^{+}\right]$i-dependent $\mathrm{Na}, \mathrm{K}$-ATPase cell surface expression and PKA activation in mpkCCD 14 cells. Confluent mpkCCDcl4 cells grown on polycarbonate filters were first preincubated in the presence of either 15 or $135 \mathrm{mM} \mathrm{Na}^{+}$without or with $10^{-6} \mathrm{M}$ lactacystin or $10^{-6} \mathrm{M}$ MG-132 for $30 \mathrm{~min}$ at $37^{\circ} \mathrm{C}$. After permeabilization by $1 \mu \mathrm{g} / \mathrm{ml}$ amphotericin B, cells were incubated for $1 \mathrm{~h}$ at $37^{\circ} \mathrm{C}$. (A and B) Cell surface $\mathrm{Na}, \mathrm{K}$-ATPase was detected as described in the legend of Figure 2. (A) Representative immunoblot showing $\mathrm{Na}, \mathrm{K}-\mathrm{ATPa} e$ cell surface expression. (B) Bars represent densitometric values expressed as the percentage of the optical density value measured in the presence of $15 \mathrm{mM} \mathrm{Na}^{+}$. Results are means $\pm \mathrm{SE}$ from six independent experiments. ${ }^{*} \mathrm{p}<$ 0.05 vs. $15 \mathrm{mM} \mathrm{Na}^{+}$values. (C) PKA activity was measured on homogenized cells using the SignaTECT cAMP-dependent Protein Kinase Assay System as described in MATERIALS AND METHODS. Results expressed as pmol ATP $\times \min ^{-1} \times \mu \mathrm{g}$ protein $^{-1}$ are means $\pm \mathrm{SE}$ from four independent experiments. ${ }^{*} \mathrm{p}<$ 0.05 vs. $15 \mathrm{mM} \mathrm{Na}^{+}$values.

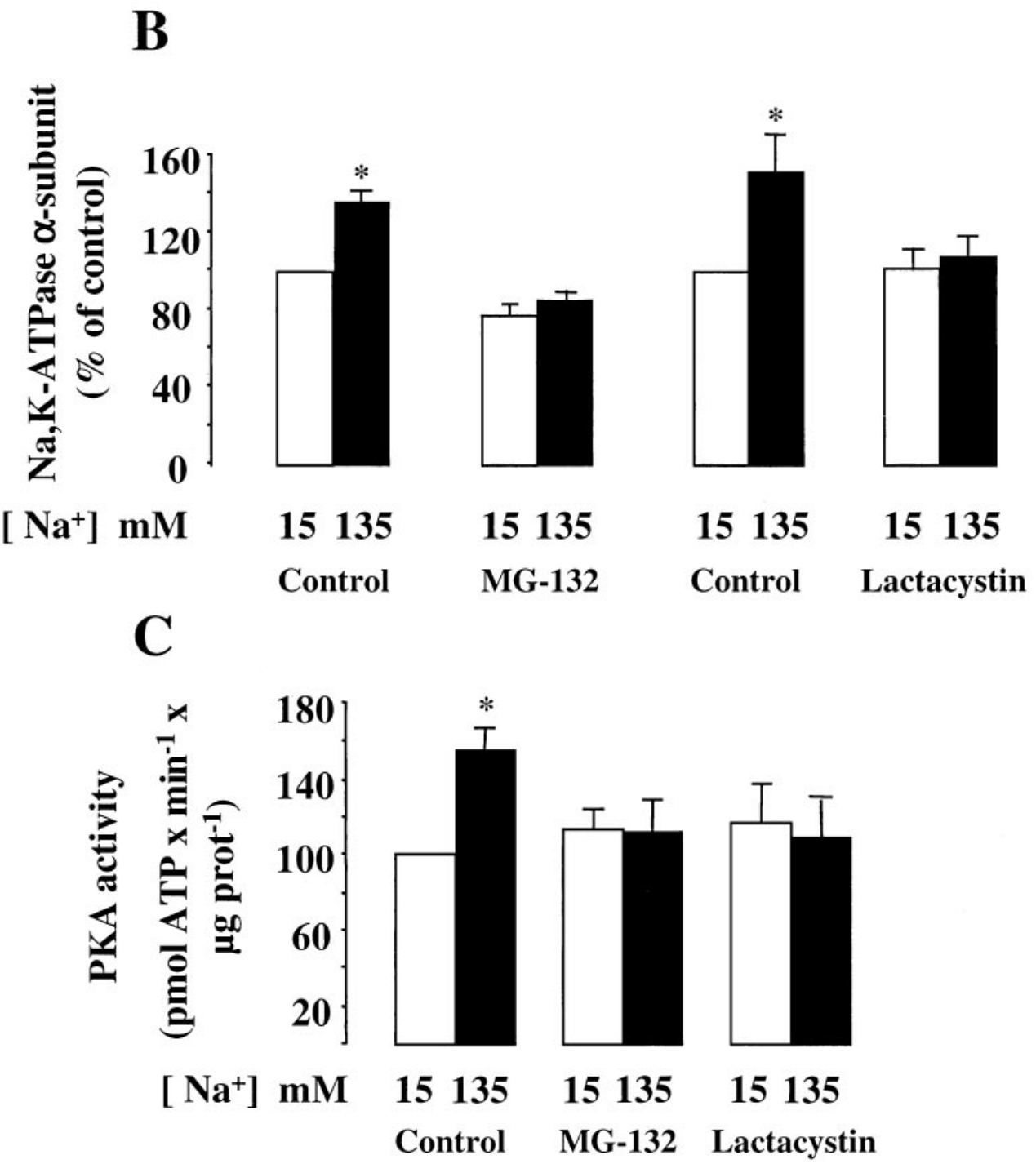

limiting step for $\mathrm{Na}^{+}$reabsorption in collecting duct principal cells was the $\mathrm{Na}^{+}$influx occurring through the apical epithelial $\mathrm{Na}^{+}$channel $(\mathrm{ENaC})$ and that the kinetic control of $\mathrm{Na}, \mathrm{K}-\mathrm{ATPase}$ by $\left[\mathrm{Na}^{+}\right] \mathrm{i}$ was sufficient to maintain the balance between the apical entry and basolateral exit of $\mathrm{Na}^{+}$. However, several studies have shown that aldosterone and vasopressin enhance both apical and basolateral steps of 
Cell surface Na,K-ATPase

\section{$\alpha$ subunit - \\ $\left[\mathrm{Na}^{+}\right] \mathbf{m M}$}

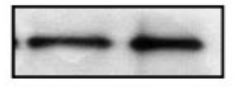

15135

Control

B

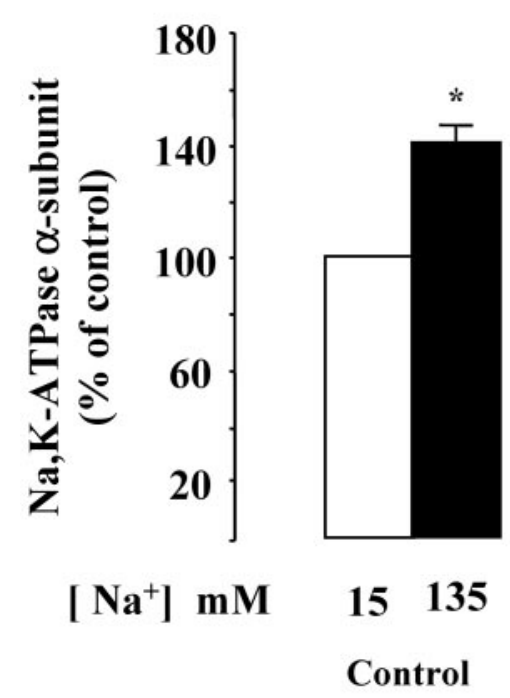

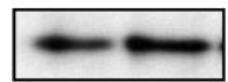

15135

Leupeptin

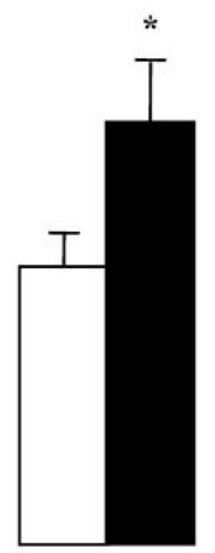

15135

Leupeptin

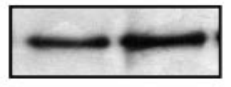

15135

\section{Chloroquine}

Figure 9. Effect of lysosomal inhibitors on $\left[\mathrm{Na}^{+}\right] \mathrm{i}$-dependent $\mathrm{Na}, \mathrm{K}-\mathrm{ATPase}$ cell surface expression in mpkCCD $\mathrm{cl}_{4}$ cells. Confluent mpkCCDcl4 cells grown on polycarbonate filters were first preincubated in the presence of either 15 or $135 \mathrm{mM} \mathrm{Na}^{+}$without or with $10^{-6} \mathrm{M}$ leupeptin or with $10^{-7} \mathrm{M}$ choloroquine for $30 \mathrm{~min}$ at $37^{\circ} \mathrm{C}$. After permeabilization by 1 $\mu \mathrm{g} / \mathrm{ml}$ amphotericin $\mathrm{B}$, cells were incubated for $1 \mathrm{~h}$ at $37^{\circ} \mathrm{C}$. (A and B) Cell surface $\mathrm{Na}$,K-ATPase was detected as described in the legend of Figure 2. (A) Representative immunoblot showing $\mathrm{Na}, \mathrm{K}$ ATPase cell surface expression. (B) Bars represent densitometric values expressed as the percentage of the optical density value measured in the presence of 15 $\mathrm{mM} \mathrm{Na}^{+}$. Results are means $\pm \mathrm{SE}$ from six independent experiments. ${ }^{*} \mathrm{p}<0.05$ vs. $15 \mathrm{mM} \mathrm{Na}^{+}$ values.

vectorial $\mathrm{Na}^{+}$transport in collecting duct principal cells through the coordinated stimulation of ENaC and $\mathrm{Na}, \mathrm{K}-$ ATPase (Palmer et al., 1982; Schafer and Troutman, 1990; Bens et al., 1999; Gonin et al., 2001; Summa et al., 2001). Such coordinated control seems to be of special importance in the renal collecting duct. Under normal conditions, luminal $\mathrm{Na}^{+}$ concentrations in CCD are quite low and any increase in $\left[\mathrm{Na}^{+}\right] \mathrm{i}$ secondary to increased $\mathrm{Na}^{+}$influx should theoretically reduce the electrochemical driving force for apical $\mathrm{Na}^{+}$ entry (Silver et al., 1993). However, because the apparent affinity of $\mathrm{Na}, \mathrm{K}$-ATPase for $\mathrm{Na}^{+}$is twice as high in the collecting duct than in the proximal tubule and thick ascending limb (Barlet-Bas et al., 1990a; Féraille et al., 1994, 1995), the kinetic reserve for a $\left[\mathrm{Na}^{+}\right] \mathrm{i}$ activation of $\mathrm{Na}, \mathrm{K}$-ATPase is much lower in the collecting duct than in the more proximal nephron segments. In view of ENaC downregulation by high $\left[\mathrm{Na}^{+}\right] \mathrm{i}$ (Kellenberger et al., 1998; Awayda, 1999), the observed increase of $\mathrm{Na}, \mathrm{K}-\mathrm{ATPase}$ cell surface expression that allows a more efficient decrease in $\left[\mathrm{Na}^{+}\right]$i suggests that the restoration of a normal $\left[\mathrm{Na}^{+}\right] \mathrm{i}$ is a priority with respect to $\mathrm{Na}^{+}$reabsorption in collecting duct principal cells. Therefore, acute fluctuations of $\left[\mathrm{Na}^{+}\right] \mathrm{i}$ may exert a rapid kinetic effect on $\mathrm{Na}, \mathrm{K}$-ATPase activity whereas sustained changes in $\left[\mathrm{Na}^{+}\right] \mathrm{i}$ would also control the number of active Na pumps present at the cell surface of CCD cells.

Our results also show that high $\left[\mathrm{Na}^{+}\right] \mathrm{i}$ induces a proportional increase in maximal hydrolytic activity and $\mathrm{Na}, \mathrm{K}-$ ATPase cell surface expression in mammalian CCDs. Therefore, the increase in the number of specific ouabain binding sites, i.e., the number of active Na-pump units at the cell surface, previously observed in response to high $\left[\mathrm{Na}^{+}\right] \mathrm{i}$ (Barlet-Bas et al., 1990b; Blot-Chabaud et al., 1990) most likely relies on an increase in Na-pump cell surface expression. This increase is observed in the absence of a variation of the total cellular pool of $\mathrm{Na}, \mathrm{K}-\mathrm{ATP}$ ase and is independent of transcriptional regulation and de novo protein synthesis (Barlet Bas et al., 1990b), strongly suggesting that translocation of intracellular Na-pumps to the plasma membrane occurs in response to increased $\left[\mathrm{Na}^{+}\right]$i. This interpretation is further supported by the PKA dependency of this process because we have recently shown the existence of an intracellular pool of Na,K-ATPase, which can be recruited rapidly to the plasma membrane in response to cAMP in collecting duct principal cells (Gonin et al., 2001). Similarly, short-term aldosterone induces the redistribution of intracellular Na-pumps to the cell surface (Summa et al., 2001). The aldosterone-dependency of both high $\left[\mathrm{Na}^{+}\right] \mathrm{i}-$ and cAMP-induced increase in cell surface expression of $\mathrm{Na}, \mathrm{K}$ ATPase (Barlet-Bas et al., 1990, Blot-Chabaud et al., 1990, Gonin et al., 2001) may suggest the requirement of (an) 
aldosterone-induced regulatory protein(s) exerting a permissive effect.

The results of this study also strongly support that PKA activation is required for the $\left[\mathrm{Na}^{+}\right] \mathrm{i}$-induced recruitment of Na-pumps to the cell surface in collecting duct principal cells: first, pharmacological inhibition of PKA prevented the $\left[\mathrm{Na}^{+}\right] \mathrm{i}$-induced increase in $\mathrm{Na}, \mathrm{K}$-ATPase cell surface expression and activity; second, high $\left[\mathrm{Na}^{+}\right] \mathrm{i}$ concomitantly stimulated PKA activity and increased $\mathrm{Na}, \mathrm{K}$-ATPase cell surface expression; third, the effects of $\left[\mathrm{Na}^{+}\right] \mathrm{i}$ and cAMP on $\mathrm{Na}, \mathrm{K}-$ ATPase cell surface expression are not additive; and finally proteasome inhibitors prevented both $\left[\mathrm{Na}^{+}\right] \mathrm{i}$-induced PKA activation and $\mathrm{Na}, \mathrm{K}-\mathrm{ATP}$ ase increased cell surface expression. It remains to be determined whether PKA directly induces $\mathrm{Na}, \mathrm{K}$-ATPase redistribution of, e.g., though phosphorylation of the $\mathrm{Na}, \mathrm{K}$-ATPase $\alpha$-subunit (Beguin et al., 1994; Feschenko and Sweadner, 1994; Fisone et al., 1994; Carranza et al., 1996b, 1998), and/or whether other signaling intermediate(s) is(are) involved.

The PKA holoenzyme is a heterotetramer consisting of two catalytic (PKAc) subunits associated with two regulatory subunits (Scott, 1991; Taylor et al., 1990; Francis and Corbin, 1994). Dissociation of the holoenzyme is induced by binding of cAMP to the regulatory subunits, which consequently alleviates autoinhibitory contacts and releases active PKAc. Our results clearly indicate that the $\left[\mathrm{Na}^{+}\right]$i-induced activation of PKA is independent of a rise in cellular cAMP content, because even in the presence of phosphodiesterase inhibitor or AVP, intracellular cAMP concentration is not altered by high $\left[\mathrm{Na}^{+}\right] \mathrm{i}$ in CCD cells. The large increase in cellular cAMP content observed in $\mathrm{Na}^{+}$-loaded amphotericin B-permeabilized cells treated with AVP indicate that cAMP did not leak out the cells and that high [Na]i did not interfere with adenylate cyclase activity. On the other hand, $\mathrm{Na}^{+}$-sensitive adenylyl cyclase stimulation (Cooper et al., 1998) does not seem to be involved in $\left[\mathrm{Na}^{+}\right] \mathrm{i}$-induced PKA activation. An alternate cAMP-independent mechanism of PKA activation has been recently described. In response to cytokines, free active PKAc is released upon dissociation of a multiprotein complex containing PKA, I $\kappa \mathrm{B} \alpha$, and NF- $\kappa \mathrm{B}$ p65 (Zhong et al., 1997; Zieger et al., 2001). Dissociation of the $\mathrm{PKAc} / \mathrm{I} \kappa \mathrm{B} \alpha / \mathrm{NF}-\kappa \mathrm{B}$ p65 complex is triggered by phosphorylation (Karin, 1999) and subsequent proteasomal degradation of $\mathrm{I} \kappa \mathrm{B} \alpha$ (Dulin et al., 2001). In addition, the association of a discrete pool of PKAc with the tonicity-responsive enhancer binding protein (TonEBP) and cAMP-independent activation of PKA in response to extracellular hypertonicity have been recently described (Ferraris et al., 2002). Incubation of cells under hypertonic conditions rapidly stimulates the transcriptional activity of TonEBP (Miyakawa et al., 1999) in a PKA-dependent manner (Ferraris et al., 2002). Our results show that PKA activation by $\left[\mathrm{Na}^{+}\right] \mathrm{i}$ is independent of cAMP and requires proteasomal activity, suggesting that $\left[\mathrm{Na}^{+}\right] \mathrm{i}$ controls the degradation rate of a regulatory protein that maintains a discrete cellular pool of PKAc in an inactive state.

\section{ACKNOWLEDGMENTS}

We thank Michelangelo Foti for helpful discussion. This work was supported in part by grants from the Swiss National Foundation 31-50830.99 and the Carlos et Elsie deReuter Foundation to E.F.

\section{REFERENCES}

Awayda, M.S. (1999). Regulation of epithelial $\mathrm{Na}^{+}$channel by intracellular $\mathrm{Na}^{+}$. Am. J. Physiol. 277, C216-C224.

Barlet-Bas, C., Cheval, L., Khadouri, C., Marsy, S., and Doucet, A. (1990a). Difference in the $\mathrm{Na}^{+}$affinity of $\mathrm{Na}^{+}, \mathrm{K}^{+}$-ATPase along the rabbit nephron: modulation by $\mathrm{K}^{+}$. Am. J. Physiol. 259, F246-F250.

Barlet-Bas, C., Khaodouri, C., Marsy, S., and Doucet, A. (1990b). Enhanced intracellular sodium concentration in kidney cells recruits a latent pool of $\mathrm{Na}, \mathrm{K}$-ATPase whose size is modulated by corticosteroids. J. Biol. Chem. 265, 7799-7803.

Beguin, P., Beggah, A.T., Chibalin, A.V., Burgener-Kairuz, P., Jaisser, F., Mathews, P.M., Rossier, B.C., Cotecchia, S., and Geering, K. (1994). Phosphorylation of the Na,K-ATPase $\alpha$-subunit by protein kinase $A$ and $C$ in vitro and intact cells. Identification of a novel motif for PKC-mediated phosphorylation. J. Biol. Chem. 269, 2443724445.

Bens, M., Vallet, V., Cluzeaud, F., Pascual-Letallec, L., Kahn, A., Rafestin-Oblin, M.E., Rossier, B.C., and Vandewalle, A. (1999). Corticosteroid-dependent sodium transport in a novel immortalized mouse collecting duct principal cell line. J. Am. Soc. Nephrol. 10, 923-934.

Blot-Chabaud, M., Wanstok, F., Bonvalet, J-P., and Farman, N. (1990). Cell-sodium-induced recruitment of $\mathrm{Na}^{+}-\mathrm{K}^{+}$-ATPase pumps in rabbit collecting tubules is aldosterone-dependent. J. Biol. Chem. 265, 11676-11681.

Carranza, M.L., Féraille, E., and Favre, H. (1996a). Protein kinase C-dependent phosphorylation of $\mathrm{Na}^{+}-\mathrm{K}^{+}$-ATPase alpha-subunit in rat kidney cortical tubules. Am. J. Physiol. 271, C136-C143.

Carranza, M.L., Féraille, E., Kiroytcheva, M., Rousselot, M., and Favre, H. (1996b). Stimulation of ouabain-sensitive ${ }^{86} \mathrm{Rb}^{+}$uptake and $\mathrm{Na}^{+}, \mathrm{K}^{+}$-ATPase $\alpha$-subunit phosphorylation by a cAMP-dependent signaling pathway in intact cells from rat kidney cortex. FEBS Lett. 396, 309-314.

Carranza, M.L., Rousselot, M., Chibalin, A.V., Bertorello, A.M., Favre, H., and Féraille, E. (1998). Protein kinase A induces recruitment of active $\mathrm{Na}^{+}, \mathrm{K}^{+}$-ATPase units to the plasma membrane of rat proximal convoluted tubule cells. J. Physiol. 511, 235-243.

Chabardès, D., Montégut, M., Imbert-Teboul, M., and Morel, F. (1984). Inhibition of $\alpha 2$-adrenergic agonists on AVP-induced cAMP accumulation in isolated collecting tubule of the rat kidney. Mol. Cell. Endocrinol. 37, 263-275.

Cooper, D.M., Schell, M.J., Thorn, P., and Irvine, R.T. (1998). Regulation of adenylyl cyclase by membrane potential. J. Biol. Chem. 273, 27703-27707.

Davies, S.P., Reddy, H., Caivano, M., and Cohen, P. (2000). Specificity and mechanism of action of some commonly used protein kinase inhibitors. Biochem. J. 351, 95-105.

Deschenes, G., and Doucet, A. (2000). Collecting duct $\mathrm{Na}^{+}, \mathrm{K}^{+}-$ ATPase activity is correlated with urinary sodium excretion in rat nephrotic syndromes. J. Am. Soc. Nephrol. 11, 604-615.

Dulin, N.O., Niu, J., Browning, D.D., Ye, R.D., and VoynoYasenetskaya, T. (2001). Cyclic AMP-independent activation of protein kinase A by vasoactive peptides. J. Biol. Chem. 276, 2082720830 .

Féraille, E., Carranza, M.L., Rousselot, M., and Favre, H. (1994). Insulin enhances sodium sensitivity of $\mathrm{Na}, \mathrm{K}-\mathrm{ATPase}$ in isolated rat proximal convoluted tubule. Am. J. Physiol. 267, F55-F62.

Féraille, E., Rousselot, M., Rajerison, R., and Favre, H. (1995). Effect of insulin on $\mathrm{Na}^{+}, \mathrm{K}^{+}$-ATPase in rat collecting duct. J. Physiol. 488 , $171-180$. 
Féraille, E., and Doucet, A. (2001). Sodium-potassium-adenosinetriphosphate-dependent sodium transport in the kidney: hormonal control. Physiol. Rev. 81, 345-418.

Feschenko, M.S., and Sweadner, K.J. (1994). Conformation-dependent phosphorylation of $\mathrm{Na}, \mathrm{K}-\mathrm{ATPase}$ by protein kinase $\mathrm{A}$ and protein kinase C. J. Biol. Chem. 269, 30436-30444.

Fisone, G. et al. (1994). Identification of the phosphorylation site for cAMP-dependent protein kinase on $\mathrm{Na}^{+}, \mathrm{K}^{+}$-ATPase and effects of site-directed mutagenesis. J. Biol. Chem. 269, 9368-9373.

Francis, S.H., and Corbin, J.D. (1994). Structure and function of cyclic nucleotide-dependent protein kinases. Annu. Rev. Physiol 56, 237-272.

Gonin, S., Deschenes, G., Roger, F., Bens, M., Martin, P.Y., Carpentier, J.L., Vandewalle, A., Doucet, A., and Feraille, E. (2001). Cyclic AMP increases cell surface expression of functional Na,K-ATPase units in mammalian cortical collecting duct principal cells. Mol. Biol. Cell 13, 255-264.

Hasler, U., Mordasini, D., Bens, M., Bianchi, M., Cluzeaud, F., Rousselot, M., Vandewalle, A., Feraille, E., and Martin, P.Y. (2002). Long term regulation of aquaporin-2 expression in vasopressinresponsive renal collecting duct principal cells. J. Biol. Chem. 277, 10379-10386.

Ferraris, J.D., Persaud, P., Williams, C.K., Chen, Y., and Burg, M. (2002). cAMP-independent role of PKA in tonicity-induced transactivation of tonicity-responsive enhancer/osmotic response element binding protein. Proc. Natl. Acad. Sci. USA 99, 16800-16805.

Karin, M. (1999). How NF- $\kappa$ B is activated: the role of the I $\kappa$ B kinase (IKK) complex. Oncogene 18, 6867-6874.

Kellenberger, S., Gautschi, I., Rossier, B.C., and Schild, L. (1998). Mutations causing Liddle syndrome reduce sodium-dependent downregulation of the epithelial sodium channel in the Xenopus oocyte expression system. J. Clin. Invest. 12, 2741-2750.

Laemmli, U.K. (1970). Cleavage of structural proteins during the assembly of the head of bacteriophage T4. Nature 227, 680-685.

Miyakawa, H., Woo, S.K., Dahl, S.C., Handler, J.S., and Kwon, H.M. (1999). Tonicity-responsive enhancer binding protein, a Rel-like protein that stimulates transcription in response to hypertonicity. Proc. Natl. Acad. Sci. USA 96, 2538-2542.
Palmer, L.G., Li, J.H.Y., Lindeman, B., and Edelman, I.S. (1982). Aldosterone control of the density of sodium channels in the toad urinary bladder. J. Membr. Biol. 64, 91-102.

Robert-Nicoud, M. et al. (2001). Transcriptome of a mouse kidney cortical collecting duct cell line: Effects of aldosterone and vasopressin. Proc. Natl. Acad. Sci. USA 98, 2712-2716.

Schafer, J.A., and Troutman, S.L. (1990). cAMP mediates the increase in apical membrane $\mathrm{Na}^{+}$conductance produced in rat CCD by vasopressin. Am. J. Physiol. 259, F823-F831.

Scott, J.D. (1991). Cyclic nucleotide-dependent protein kinases. Pharmacol. Ther. 50, 123-145.

Silver, R.B., Frindt, G., Windhager, E.E., and Palmer, L.G. (1993). Feedback regulation of $\mathrm{Na}$ channels in rat CCT. I. Effects of inhibition of Na pump. Am. J. Physiol. 264, F557-F564.

Skou, J.C. (1998). Nobel lecture. The identification of the sodiumpotassium pump. Biosci. Rep. 18, 155-169.

Summa, V., Mordasini, D., Roger, F., Bens, M., Martin, P.Y., Vandewalle, A., Verrey, F., and Feraille, E. (2001). Short term effect of aldosterone on $\mathrm{Na}, \mathrm{K}-\mathrm{ATPase}$ cell surface expression in kidney collecting duct cells. J. Biol. Chem. 276, 47087-47093.

Taylor, S.S., Buechler, J.A., and Yonemoto, W. (1990). cAMP-dependent protein kinase: framework for a diverse family of regulatory enzymes. Annu. Rev. Biochem. 59, 971-1005.

Therien, A.G., and Blostein, R. (2000). Mechanisms of sodium pump regulation. Am. J. Physiol. 279, C541-C566.

Vandewalle, A., Bens, M., and Duong Van Huyen, J.-P. (1999). Immortalized kidney epithelial cells as tools for hormonally regulated ion transport studies. Curr. Opin. Nephrol. Hypertens. 8, 581-587.

Zhong, H., SuYang, H., Erdjument-Bromaage, H., Tempst, P., and Ghosh, Z. (1997). The transcriptional activity of NF- $\kappa$ B is regulated by the I $\kappa$ B-associated PKAc subunit through a cyclic AMP-independent mechanism. Cell 89, 413-424.

Zieger, M., Tausch, S., Henklein, P., Nowak, G., and Kaufmann, R. (2001). A novel PAR-1-Type thrombin receptor signaling pathway: cyclic AMP-independent activation of PKA in SNB-19 glioblastoma cells. Biochem. Biophys. Res. Com. 282, 952-957. 